\title{
Associative Language Represenration of Mental States: Phenomenological Characteristics
}

\section{Representación asociativa del lenguaje de los estados mentales: características fenomenológicas}

\author{
Ekaterina Mikhailovna Alekseeva \\ $\mathrm{PhD}$ in Psychology, Associate Professor at the Department of Foreign languages and \\ Translation, Institute of International Relations, Kazan federal university, Russia \\ ORCID: http://orcid.org/0000-0002-6864-1491
}

\section{Ksenia Olegovna Prosyukova}

$\mathrm{PhD}$ in Pedagogy, Associate Professor at the Department of Foreign languages and Translation, Institute of International Relations, Kazan federal university, Russia

ORCID: http://orcid.org/0000-0002-8567-4658

Received 08-12-20 Revised 09-30-20

Accepted 10-13-20 On line 01-14-21

*Correspondence

Email: ealekseeva@list.ru
Cite as:

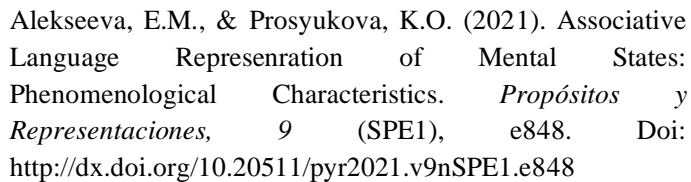




\section{Summary}

This paper is focused on description of phenomenological characteristics of associative fields of mental states. The method of free association is used in the study. 61 students of both sexes aged 18 to 21 took part in the research. Group 1 had to write down their associations with 25 concepts of mental states. Group 2 participated in an associative experiment: participants had to name orally a single association with each of 25 mentioned mental states. The analysis of associative fields having been reconstructed on the basis of written and oral associations, demonstrated that all of them bear both equal and specific marks. Most of the states under study (as reflection, delight, joy, melancholy, hesitation, fatigue, tranquility) led to written and verbal associations that form the core and perinuclear layers coincided with only few differences, in particular, the forms of their expression. Written and oral associations with individual states (as happiness, love, gaiety, loneliness) could differ significantly from each other. The study reveals the mechanism of formation of specific associations and the characteristics of specific associations based on the concept of mental states. The identification of universal and specific components of the associative representation of states can demonstrate important regularities in shaping the structure of a person's ideas about their inner life.

Keywords: linguistics, language, associative representation, association experiment, written and oral association, mental state, word, speech, speech response.

\section{Resumen}

Este artículo se centra en la descripción de las características fenomenológicas de los campos asociativos de los estados mentales. En el estudio se utiliza el método de asociación libre. En la investigación participaron 61 estudiantes de ambos sexos de entre 18 y 21 años. El grupo 1 tuvo que escribir sus asociaciones con 25 conceptos de estados mentales. El grupo 2 participó en un experimento asociativo: los participantes debían nombrar oralmente una sola asociación con cada uno de los 25 estados mentales mencionados. El análisis de los campos asociativos, reconstruidos a partir de asociaciones escritas y orales, demostró que todos ellos tienen marcas iguales y específicas. La mayoría de los estados estudiados (como reflexión, deleite, alegría, melancolía, vacilación, fatiga, tranquilidad) llevaron a asociaciones escritas y verbales que forman el núcleo y las capas perinucleares coincidieron con pocas diferencias, en particular, las formas de su expresión. Las asociaciones escritas y orales con estados individuales (como felicidad, amor, alegría, soledad) podrían diferir significativamente entre sí. El estudio revela el mecanismo de formación de asociaciones específicas y las características de asociaciones específicas basadas en el concepto de estados mentales. La identificación de componentes universales y específicos de la representación asociativa de estados puede demostrar importantes regularidades en la configuración de la estructura de las ideas de una persona sobre su vida interior.

Palabras clave: lingüística, lenguaje, representación asociativa, experimento de asociación, asociación escrita y oral, estado mental, palabra, habla, respuesta del habla.

\section{Introduction}

Associations have been under study for a long time in different fields - psychology, social studies, linguistics, psycholinguistics, etc.; a wide range of experiments have been undertaken based on the method of associative experiment, both controlled and free associations (Pautova, 2007; Rodionova \& Privalova, 2015; Kondrateva et al., 2018; Nikolaeva et al., 2019; Sitdikova et al., 
2019). The aim of association studies is to reconstruct associative fields and study associative representation of various phenomena.

One of the wide-spread methods is an associative experiment, when participants are asked to name their associations with certain concepts in writing. A less common method is to study oral associations, including oral associations obtained during a psycholinguistic experiment conducted in a compressed time frame.

The study of the associative representation of mental phenomena (and, above all, emotions and mental states) is one of the main scientific interests. There are psychological studies devoted to the structure of knowledge about emotions and development of such knowledge (Prusakova \& Sergienko, 2002), representation of emotions on different conscious levels (Dorfman, 1997), the level organization of mental states representations and their linguistic characteristics (Chernov \& Alekseeva, 2016; Alekseeva \& Bulatova, 2016; Bulatova \& Alekseeva, 2016; Alexeyeva \& Chernov, 2015).

However, it is obvious that the problem of interrelation between universality and specificity of associative ideas about mental states still exists. The states are among the most individual phenomena of the psyche, and the identification of universal and specific components can reveal the important patterns in shaping the structure of associative ideas about the world as a whole and about a human being.

The aim of this study is to reveal associations to various mental states and to determine their nature - if they are typical or individual, single or multiple. The tasks included reconstruction of associative fields of mental states and a comparative analysis of associative fields with components — written associations and associative fields consisting of oral reactions. The novelty lies in its experimental procedure, which allows measuring the time of speech reaction to stimuli with sufficiently high accuracy, as well as recording oral associative reactions for their subsequent qualitative analysis.

\section{Methods}

The key method is the method of free association. Two groups of respondents participated in the experiment. The first group included 30 students of both sexes aged 18 to 21 . The group was asked to write associations with 25 concepts of mental states.

The second group consisted of 31 students of both sexes aged 18 to 21 years. An associative experiment was carried out, developed on the basis of the DMDX program, which allows measuring duration of speech reactions with the accuracy to a millisecond (Forster \& Forster, 2003). The participants were asked to verbalize one association with each of the 25 concepts of mental states.

Instructions for the second group were printed on a sheet of paper and were as follows:

"Good afternoon, dear participant!

Our research is an associative experiment. We deal with associations caused by mental states.

You will see the names of mental states on the screen. Your task is to name the first association you have as quickly as possible.

Before presenting a name of a certain mental state you will see a cross on the screen, it will help you to focus your attention. The cross is a sign that you need to concentrate. 
Answer as quickly as possible, do not hesitate for a long time. Do not rely on anyone in your answers. There are no good or bad answers.

Thank you very much for your assistance!"

Thus, during the experiment, the participants were asked to name associations caused by the stimuli shown on the screen. The stimuli were the names of the following mental states reflection, fatigue, delight, tranquility, loneliness, joy, insecurity, pity, pleasure, jealousy, sympathy, expectation, love, exhaustion, remorse, affection, interest, gaiety, embarrassment, happiness, compassion, excitement, buoyancy, inspiration. These states were not selected randomly, all of them are the most typical for students.

\section{Results}

The data obtained from the first group was analyzed; we selected those states that had a wellstructured core (associations of more than 30\% of respondents), perinuclear layers (less than $30 \%$ of respondents) and peripheral associations (single associations).

From $10 \%$ to $26.7 \%$ of respondents from the first group wrote down multiple associations (more than one) with each mental state.

The responses of the second group have been analyzed regarding the time of their reaction with CheckVocal program (Protopapas, 2007). Speech reactions have been analyzed on a qualitative basis too.

The associative fields of emotional states deserve special attention. Love (23\%), family $(13.3 \%)$, life and lightness (10\%), smile, peace and joy (6.7\%) are associated with the state of happiness. The periphery of the associative field "happiness" includes child, growth, inspiration, laughter $(3.3 \%)$. The number of multiple associations equaled $23.3 \%$. The following oral associations were included in the perinuclear layers of the associative field: joy (in 20\%), family (10\%), delight (6.6\%). Euphoria, positive emotion, the comprehensible, confidence, sun, laughter, "everything goes as it is planned", some task, meeting with friends, puppies, a trip abroad, diploma, children, warmth in the palms, fun, love, peace, being near were the peripheral components.

Happiness (13.3\%), spring and inspiration (10\%), euphoria and flying (6.7\%) are associated with the state of love. Soul, magic, lightness and joy formed the periphery of this associative field and equaled 3.3\%. The associative field of this state, reconstructed on the basis of oral associations, has the following features: the core field is missing. The perinuclear layers are filled with such components as inspiration (14.2\%), joy (10.7\%), euphoria (7.1\%), sympathy (7.1\%). Participants have filled the periphery with such associations as young people, mutual feeling, amazing, ethereality, heart, rainbow, delight, new movie, books, flirting, spring, young man, teenager, candy, loftiness, happiness, jealousy, permanent, youth.

The associative core of gaiety: food (16.7\%), laughter (13.3\%), ice cream (10\%), bathroom and comedy (6.7\%). The periphery included: people, running, tranquility, joke (3.3\%). The perinuclear layers of the associative field reconstructed on the basis of oral associations included: joy (23.3\%), laughter (13.3\%), friends / meeting with friends (10\%), holiday (6.6\%). The periphery consisted of emotions, fireworks, sports, candy, weekends, good company, pastime, smile, interest, the sky is blue, alcohol, noise, optimism, happiness, cheerful, wantonness, always.

The majority of respondents associated delight with joy (30\%), happiness (26.7\%), surprise (10\%), fireworks (6.7\%). The periphery of the associative field includes beauty, interest, insight, strength (3.3\%). The number of multiple associations was $36.7 \%$. The associative field, defined on the basis of oral speech reactions, also has a well-represented core, filled with an association of joy (40\%). The perinuclear layer of the associative field is filled with such associations as happiness (23\% of respondents), holiday/happy holiday (6\%), event/ joyful event 
(6\%). The periphery is represented by such associations as life, emotions, love, friends, new plans, fireworks.

The state of joy is mainly associated with happiness (16.7\%), good mood (10\%), sunny day, lightness and rainbow (6.7\%). Wedding, family, fireworks, chocolate, tranquility (3.3\%) belong to the periphery of this associative field. The analysis of the oral speech reactions demonstrated that the associative field of this mental state does not have any well-represented core. Happiness (20\%), sun (10\%), laughter (6\%), delight (6\%), gift (6\%), meeting with friends $(6 \%)$, holiday (6\%) represent the perinuclear layer. Female friends, satisfaction, home, handclaps, good mood, summer, orange, diploma, fun, success are on the periphery of the field.

The core of the associative fields "fatigue" included: sleep (23.3\%), being tired (16.7\%), study (10\%). Sadness, severity, exhaustion, laziness (3.3\% each) entered the periphery of this associative field. When analyzing speech reactions to the concepts of mental states with a dominant physiological component, it was revealed that the perinuclear layer (the core is absent) of the associative field "fatigue" included sleep / drowsiness (22\%), work (19\%), lack of energy $(6 \%)$, laziness $(6 \%)$, bed (6\%), burden (6\%). The word "fatigue" itself as a speech reaction was a part of the core of the associative field "exhaustion" (36\%). The perinuclear layers of the associative field also included exams (10\%) and sleep (6\%).

The negative states of low mental activity also have their own features (see Table 1).

Table 1. Characteristics of the associative field "melancholy"

\begin{tabular}{ccc}
\hline Melancholy & Written associations & Oral associations \\
\hline The core & sadness $(20 \%)$, grief $(13,3)$, & sadness $(30 \%)$ \\
Perinuclear layer & home $(13,3)$, loneliness & $(23 \%)$, tears $(10 \%)$, \\
& $(6,7 \%)$, & boredom $(6 \%)$ \\
Peripheral layer & nonsense, love, tea, music & disappointment, road, \\
& & loneliness, love, rain, bed, \\
event, mom
\end{tabular}

Thus, sadness (20\%), grief and home (13.3\%), loneliness (6.7\%) shaped the first perinuclear layer of the associative field. Multiple associations made up $26.7 \%$. The associative field "melancholy", reconstructed on the basis of oral reactions, has the following characteristics: the core contains sadness $(30 \%)$, grief $(23 \%)$, tears $(10 \%)$, boredom $(6 \%)$ formed the perinuclear layers. Associations formed the periphery were frustration, bed, event, mom, road, loneliness, love, rain.

The core of the associative field "loneliness", reconstructed on the basis of written associations, is formed as follows: boredom (13.3\%), peace and sadness (10\%), grief (6.7\%), the periphery included rain, emptiness, music, darkness, dullness (3.3\%). The analysis of oral associations demonstrated that the state of loneliness is characterized by a well-represented core of the associative field - boredom (30\%). Tranquility (11\%) and sadness (7\%) formed a perinuclear layer. Grief, wolf, being alone, rain, dormitory, reading books, evening, no friends, a desire to be alone, old age, bad, empty room, silence, trouble shaped the peripheral layer.

Uncertainty (20\%), fear (10\%), doubt (6.7\%) are associated with hesitancy. Fatigue, passing tests, teenager, running around in circles, excitement and recognition (3.3\% each) entered the periphery of the associative field. The perinuclear layers of the associative field are represented by the following oral associations: uncertainty (25\%), fear (12.5\%), modesty (8.3\%). The periphery is formed by problems, incomprehensibility, task, self-esteem, practical class, fear, conversation, inability to answer a question, taking a step, instability, embarrassment, restraint, drawback. 
Thought (16.7\%), tranquility, book (6.7\%) are associated with reflection. The peripheral layer includes fatigue, despondency, mental activity, anxiety, and isolation (3.3\%). The number of multiple associations was $30 \%$. In contrast to the above mentioned associations, the associative field based on oral speech reactions to the concept of "reflection" consists of a well-represented core with such components as thought/idea (48\%), brain (6\%), study (6\%), exam (6\%), reverie $(6 \%)$. The periphery is represented by such associations as books, thoughts, tasks, class, wind, reflection.

The perinuclear layers of the associative field "tranquility" consist of such written associations as silence and peace (13.3\%), book (10\%), harmony (6.7\%). Associative periphery was filled with associations such as tea, vigor, diligence, comfort, evening (3.3\%). The perinuclear layers of the associative field based on oral associations are filled with peace/tranquility (25\%), sleep and silence (10.7\% each), rest, home (7.1\%). On the periphery: sincerity, balancing, comfort, nirvana, dreams, evening, depression, sea, nothing, bed, satisfaction.

\section{Discussion}

Idea or thought is associated with the cognitive state of reflection. This is the most common written and oral association, but it was mentioned orally three times more often than in writing.

Similarly, the state of delight is mainly associated with joy, both the written and oral responses, joy formed the core of the associative field.

Happiness as a written and oral association was a component of the perinuclear layers of the same associative field.

In most cases sadness was associated with grief-in written responses it became a part of the perinuclear layer, in oral form it became the core of the associative field.

Uncertainty is associated with indecision, which is a component of the perinuclear layers in both associative fields. Fear is also a component of the perinuclear layers, it has approximately the same share in both groups (10\% (as a written association) and $12.5 \%$ (as an oral association)).

Sleep, as an association, is a component of the perinuclear layers of the associative field "fatigue" - more than $20 \%$ of respondents in both groups named it orally or in writing. The second frequent association is exhaustion (16.7\% of respondents indicated it in writing) and work (frequent oral association in 19\% of responses).

Peace is presented in the associative field of "tranquility" as both a written and an oral association, but as an oral one it was named twice more often (25\% against $13.3 \%)$. The association silence became an element of the perinuclear layers of the associative field $(13.3 \%$ of respondents indicated it as a written association, $10.7 \%$ as an oral one).

As for the other states under study: the content of their associative fields, reconstructed on the basis of written and oral responses, is characterized by specific features.

The most frequent written association with the concept of happiness is love, while verbally, joy was mentioned more often.

Happiness is the most frequent written association with the state of love, and the most frequent verbal association is inspiration. joy.

The most frequently associated with the state of gaiety was the word food, and verbally - 
The associative field of loneliness led us to one of the most exciting conclusions: the oral association sadness was offered by $30 \%$ of respondents and formed the core, while it is absent among written associations on either core or perinuclear layers (boredom is the most frequently mentioned written association with only $13.3 \%$ responses).

\section{Summary}

The analysis of associative fields reconstructed on the basis of written and oral associations has shown that they can exhibit both similar and specific marks.

In the majority of mental states under study (for example, reflection, delight, joy, sadness, indecision, fatigue, tranquility) written and oral associations that form the core and perinuclear layers, coincided.

In individual states (for example, happiness, love, gaiety, loneliness), written and oral associations differ significantly from each other.

\section{Conclusions}

The obtained empirical data allowed reconstruction of the associative fields of mental states on the basis of oral and written associations given by respondents and provided description of their phenomenological characteristics.

The study has a great theoretical and practical significance. It reveals the mechanism of formation of specific associations with mental states. The identification of universal and specific components of the associative representation of states can demonstrate the important features for the formation of human ideas about their inner life.

The directions for future research provide possibilities for a cross-cultural study of associative representation of mental states among representatives of other cultures, containing both assessment and situational components of the associative fields.

\section{Acknowledgements}

The work is performed according to the Russian Government Program of Competitive Growth of Kazan Federal University.

\section{References}

Alekseeva, E.M., \& Bulatova, A.M. (2016). Associative representation of mental state concepts in the bilingual mental lexicon. Turkish online journal of design art and communication, 6, 2309-2316.

Alexeyeva, E.M., \& Chernov, A.V. (2015). Representation of mental states: Associative level. The Social Sciences (Pakistan), 10(7), 1959-1963.

Bulatova, A.M., \& Alekseeva, E.M. (2016). Lexical Objectivation Means For The Emotional Concept "Fear" In German Publicistic Discourse. Turkish online journal of design art and communication, 6, 2334-2339.

Chernov, A.V., \& Alekseeva, E.M. (2016). Estimated Characteristics Of Mental States'representations. Journal of organizational culture, communications and conflict, 20, 94.

Dorfman, L.Y. (1997). Emotions in Art: Theoretical Approaches and Empirical Research, Moscow, $424 \mathrm{p}$.

Forster, K.I., \& Forster, J.C. (2003). DMDX: A Windows display program with millisecond accuracy. Behavior research methods, instruments, \& computers, 35(1), 116-124. 
Kondrateva, I., Sabirova, D., \& Plotnikova, N. (2018). Subjectivity functions in reflexive and intercultural process of linguistic development. Cypriot Journal of Educational Sciences, 13(4), 529-536.

Nikolaeva, O., Kozlova, Y., \& Mefodeva, M. (2019). Students' Effective Psychological and Pedagogical Interaction at the English Classes. Research in Applied Linguistics, 10(Proceedings of the 6th International Conference on Applied Linguistics Issues (ALI 2019) July 19-20, 2019, Saint Petersburg, Russia), 1049-1056.

Pautova, L.A. (2007). Associative experiment: the experience of sociological application. Sociology: methodology, methods, mathematical models, 24, 149-168.

Protopapas, A. (2007). Check Vocal: A program to facilitate checking the accuracy and response time of vocal responses from DMDX. Behavior research methods, 39(4), 859-862.

Prusakova, O.A., \& Sergienko, E.A. (2002). Representations of the Emotions by the Children Aged From 3 to 6 Years. Scientific Search, 3(1), 51-64.

Rodionova, T.V., \& Privalova, I.V. (2015). Associative experiment as one of research methods of physicians language consciousness. News of the Saratov university. New series. Series: Philology, journalism], 15(2), 13-17.

Sitdikova, F.B., Khisamova, V.N., \& Mutigullina, Z.A. (2019). Implicit negation in Tatar phraseology. Journal of Sociology and Social Anthropology, 10(4), 175-179.

Sternin, I. A. (2015). Description methods of words semantics, Moscow-Berlin: Direkt-Media, $34 \mathrm{p}$. 